\title{
Water purification and the incidence of fractures in patients receiving home haemodialysis supervised by a single centre: evidence for "safe" upper limit of aluminium in water
}

\author{
M M PLATTS, G OWEN, S SMITH
}

\begin{abstract}
Between 1968 and 1980 fractures occurred in 56 of 284 patients treated by home haemodialysis in the Sheffield area for longer than one year. Patients sustained four times as many fractures while using dialysate prepared with water containing more than $1.0 \mu \mathrm{mol}$ aluminium per $1(2.7 \mu \mathrm{g} / 100 \mathrm{ml})$ than while using water containing a smaller concentration. When aluminium was removed from water by deionisation the incidence of fractures diminished during the next year and no patient developed dialysis encephalopathy.

These findings show that $1.0 \mu \mathrm{mol} / 1$ is a safe maximum concentration of aluminium in water for use in home haemodialysis. It can be detected by the colorimetric aluminium analyses used by many water authorities. When financial resources are limited it is expedient to reserve aluminium analyses by electrothermal atomic absorption for plasma from patients receiving regular haemodialysis. Ingestion of aluminium hydroxide contributes significantly to the increased plasma aluminium concentration of these patients.
\end{abstract}

\section{Introduction}

In 1972 Posen et al described some patients treated by regular haemodialysis who had fracturing osteodystrophy which was apparently cured when the water used to prepare dialysate was deionised. ${ }^{1}$ Subsequently Pierides found that bone from this type of patient usually shows a histological picture of osteomalacia which is not cured by vitamin $\mathrm{D}$ analogues. ${ }^{2} \mathrm{~A}$ particularly high incidence of fractures occurs in patients with dialysis encephalopathy. Both of these conditions are more common when patients use dialysate containing a high concentration of aluminium. ${ }^{3-5}$ In patients receiving dialysis fractures are more common than encephalopathy, but an increased incidence of fractures may serve as a marker for those at greater risk of developing encephalopathy.

Fractures and dialysis encephalopathy have become less common in most units since implementing measures to reduce the aluminium concentration in water. ${ }^{6}$ Over the past 10 years, however, phosphate binders, vitamin $\mathrm{D}$ analogues, parathyroidectomy, and other unidentified variations in management have been used to prevent and treat other types of renal osteo-

University of Sheffield

M M PLATTS, MD, FRCP, reader in medicine (retired)

Northern General Hospital, Sheffield

G OWEN, BSC, FRCP, consultant in chemical pathology

Royal Hallamshire Hospital, Sheffield

S SMITH, SRN, research assistant

Correspondence and requests for reprints to: Dr M M Platts, 47 Coldwell Lane, Sheffield S10 5TJ. dystrophy in which fractures may occasionally occur. The use of these measures has varied in different dialysis units over the period. We have therefore attempted to determine the influence of differences in water composition and the effects of deionisation on the incidence of fractures in the same unit over 13 years. Our observations suggest a level to which aluminium concentration in water used for dialysis should be reduced to prevent dialysis encephalopathy and fractures. Water treatment is expensive, and (certainly in the United Kingdom) unnecessary expenditure on this may prevent other patients with end stage renal failure from receiving treatment at all.

\section{Present study}

\section{ORGANISATION OF SHEFFIELD HAEMODIALYSIS UNIT}

Regular intermittent haemodialysis was started in Sheffield in 1967. Our patients come from Sheffield and a surrounding area of about 200 square miles $\left(518 \mathrm{~km}^{2}\right)$ and receive their domestic water from many different sources. Some $90 \%$ of the patients eventually perform dialysis in their homes but all are initially trained in Lodge Moor Hospital in Sheffield for about six months.

Patients receive dialysis for four and a half to six hours three times a week using a $1 \mathrm{~m}^{2}$ Kiil dialyser or similar disposable dialyser. All use similar proportionating equipment and commercial concentrate for preparing dialysate. The average values for calcium and aluminium found in routine analyses of reservoir water by water authorities are used at the start of home treatment to determine the type of apparatus to be used for water purification. Between 1967 and 1974 water softeners were installed in patients' homes where the water contained more than $2.5 \mathrm{mmol}$ calcium per $1(10.0 \mathrm{mg} / 100 \mathrm{ml})$, but in soft water areas such as Sheffield water treatment was not used. In 1974 deionisation of the water at Lodge Moor began because we were convinced that there was an unidentified "toxin" in the water in Sheffield which was causing the high incidence of dialysis encephalopathy and fractures in the district. ${ }^{7}$ In 1977, when aluminium became the suspected poison, ${ }^{8}$ mixed bed deionisers with conductivity monitors were installed in homes where the water authority analyses showed an aluminium concentration exceeding $3.7 \mu \mathrm{mol} / 1(10.0 \mu \mathrm{g} /$ $100 \mathrm{ml}$ ), and since 1978 deionisers have been used where aluminium concentrations exceeded $1.85 \mu \mathrm{mol} / 1(5.0 \mu \mathrm{g} / 100 \mathrm{ml})$. Reverse osmosis was not used during the study period.

Monitoring the water aluminium concentration by electrothermal atomic absorption was not possible in Sheffield until 1982, after the clinical survey had finished. Aluminium hydroxide and vitamin D analogues were prescribed as clinically indicated but were not used routinely. There were no other geographically determined differences in the management of our patients, and all attended the same clinic.

\section{MEASUREMENT TECHNIQUES AND CLINICAL STUDY}

Aluminium concentrations were measured by the water authorities using the pyrocatechol method. ${ }^{9}$ The lower limit of accuracy of that method is about $1.0 \mu \mathrm{mol} / 1(2.7 \mu \mathrm{g} / 100 \mathrm{ml})$. After the conclusion of the survey of fractures aluminium concentrations were measured by electrothermal atomic absorption using a Perkin Elmer 4000. This technique has greater sensitivity and is also suitable for serum samples. During 1982 raw and purified samples of water from 
patients' homes and serum samples were analysed for aluminium by this technique.

Fractures rarely occur in the first year of haemodialysis, during which our patients spend several months at Lodge Moor Hospital and then start dialysis at home. For this study we therefore ignored the first year of haemodialysis for each patient. We studied all patients who received haemodialysis at home under the supervision of the Sheffield unit for more than one year between 1968 and December 1980. The patients were divided into the following three groups according to the type of water usually used to prepare dialysate.

Group 1 used untreated or softened water which initial water authority analysis had shown to contain less than $1.85 \mu \mathrm{mol}$ aluminium per $1(5 \cdot 0 \mu \mathrm{g} / 100 \mathrm{ml})$.

Group 2 used untreated or softened water in which similar analyses had detected more than $1.85 \mu \mathrm{mol}$ aluminium per 1 .

Group 3 used deionised water which before treatment had contained more than $1.85 \mu \mathrm{mol}$ aluminium per 1 .

Individual patients moved from one group to another if the type of water used was changed.

Patients underwent yearly radiography of skull, chest, pelvis, and hands, and radiographs were also taken at other times if symptoms suggested a fracture. The percentage of patients who had a fracture in each year was calculated. Patients with multiple fractures were counted once in each separate calendar year in which a fracture occurred. Years in which there was an aggregate of less than 10 patient years of treatment are omitted from the analysis.

\section{Results}

Altogether 284 patients were studied, of whom 56 had at least one fracture $(19.7 \%)$. Pseudofractures were not seen and most of the fractures occurred without undue trauma.

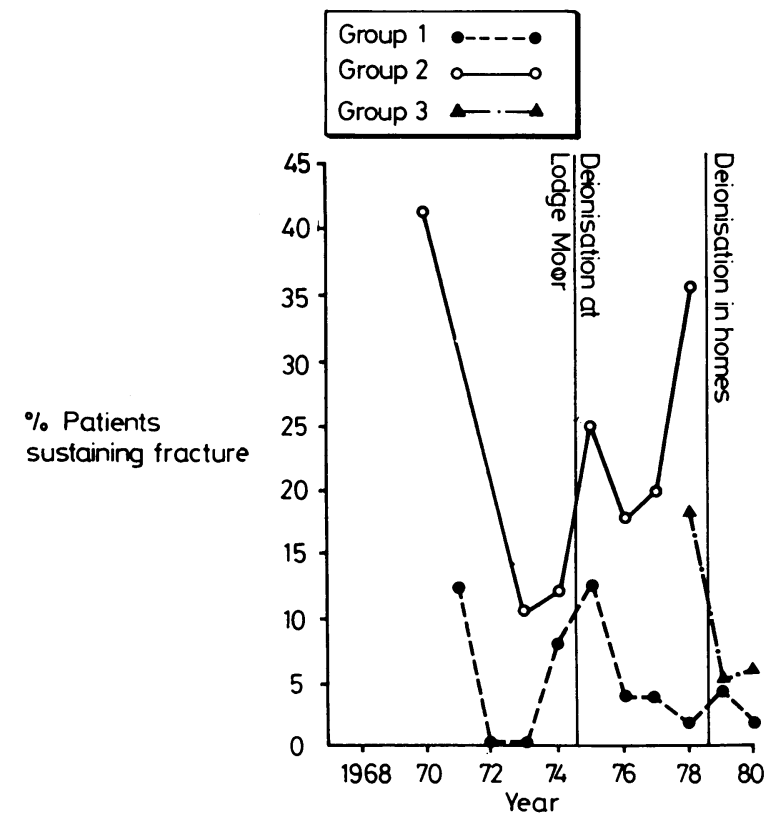

FIG 1-Percentage of patients receiving regular haemodialysis who sustained fracture each year related to concentration of aluminium in water used to prepare dialysate. (Group 1: untreated water, aluminium concentration $<1.85 \mu \mathrm{mol} / 1(<5.0 \mu \mathrm{g} /$ $100 \mathrm{ml}$ ); group 2: untreated water, aluminium concentration $>1.85 \mu \mathrm{mol} / 1$ ( $>5.0 \mu \mathrm{g} / 100 \mathrm{ml})$; group 3: deionised water.)

There was a higher incidence of fractures in group 2 than in groups 1 and 3 (fig 1 ; table). Among the 56 patients who had fractures the incidence of fractures was 0.028 a month while using water containing more than $1.85 \mu \mathrm{mol}$ aluminium per $1,0.0325$ a month during the first year in which deionised water was used after a period of dialysis with water containing a high concentration of aluminium, and 0.017 a month when using water with a low concentration of aluminium at all other times.

Figure 2 shows the concentrations of aluminium measured by the
Incidence of fractures in patients using water with various aluminium concentrations

\begin{tabular}{|c|c|c|c|}
\hline Year & Patient years of treatment & $\begin{array}{c}\text { No of patients } \\
\text { developing fractures }\end{array}$ & $\%$ with fractures \\
\hline \multicolumn{4}{|c|}{ Group 1 (untreated water; aluminium concentration $<1.85 \mu \mathrm{mol} / \mathrm{l}(-5.0 \mu \mathrm{g} / 100 \mathrm{ml})$} \\
\hline $\begin{array}{l}1971 \\
1972 \\
1973 \\
1974 \\
1975 \\
1976 \\
1977 \\
1978 \\
1979 \\
1980\end{array}$ & $\begin{array}{l}16 \cdot 5 \\
25 \cdot 5 \\
30 \cdot 5 \\
38 \cdot 0 \\
48 \cdot 0 \\
55 \cdot 0 \\
56 \cdot 5 \\
61 \cdot 5 \\
70 \cdot 0 \\
71 \cdot 0\end{array}$ & $\begin{array}{l}2 \\
0 \\
0 \\
3 \\
6 \\
2 \\
2 \\
1 \\
3 \\
1\end{array}$ & $\begin{array}{c}12.5 \\
0 \\
0 \\
7.9 \\
12.5 \\
3.6 \\
3.5 \\
1.6 \\
4.3 \\
1.4\end{array}$ \\
\hline \multicolumn{4}{|c|}{ Group 2 (untreated water; aluminium concentration $=1.85 \mu \mathrm{mol} / \mathrm{l}(5.0 \mu \mathrm{g} / 100 \mathrm{ml})$ ) } \\
\hline $\begin{array}{l}1970 \\
1973 \\
1974 \\
1975 \\
1976 \\
1977 \\
1978\end{array}$ & $\begin{array}{l}12.0 \\
10.0 \\
16.5 \\
20.5 \\
29.0 \\
35.0 \\
14.0\end{array}$ & $\begin{array}{l}5 \\
1 \\
2 \\
5 \\
5 \\
7 \\
5\end{array}$ & $\begin{array}{l}41 \cdot 7 \\
10 \cdot 0 \\
12 \cdot 1 \\
24 \cdot 4 \\
17 \cdot 2 \\
20 \cdot 0 \\
35 \cdot 7\end{array}$ \\
\hline \multicolumn{4}{|c|}{ Group 3 (deionised water) } \\
\hline $\begin{array}{l}1978 \\
1979 \\
1980\end{array}$ & $\begin{array}{l}28 \cdot 0 \\
45 \cdot 5 \\
54 \cdot 5\end{array}$ & $\begin{array}{l}5 \\
2 \\
3\end{array}$ & $\begin{array}{r}17.9 \\
4.4 \\
5.5\end{array}$ \\
\hline
\end{tabular}

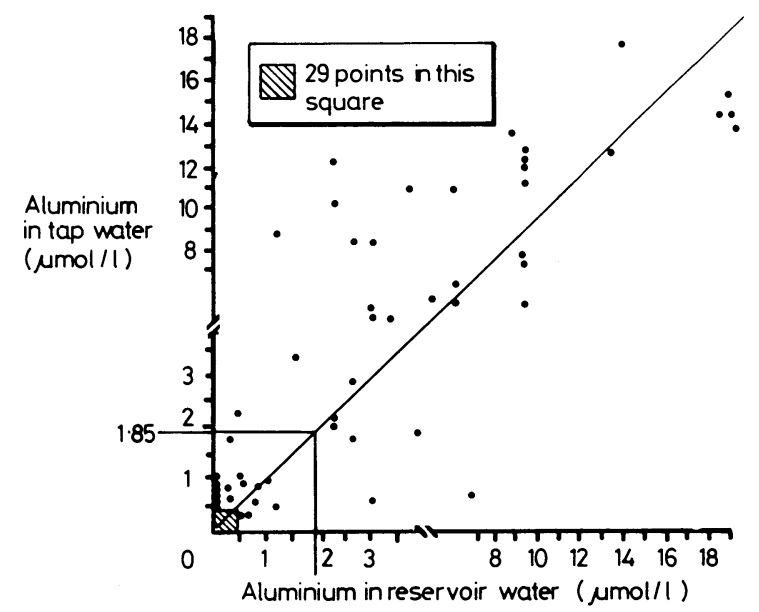

FIG 2-Correlation between aluminium concentrations in reservoir water supplied to home (measured by colorimetry) and those in water from domestic tap (measured at later date by electrothermal atomic absorption).

Conversion: SI to traditional units-Aluminium: $1 \mu \mathrm{mol} / 1 \approx$ $2 \cdot 7 \mu \mathrm{g} / 100 \mathrm{ml}$.

water authorities in reservoir water at the start of home dialysis compared with measurements by electrothermal atomic absorption made in 1982 on tap water in the patients' homes. Although the times of sampling were often separated by several years and two different analytical methods were used, there was good agreement. In only three out of 49 instances did the concentrations measured by electrothermal atomic absorption exceed $1.85 \mu \mathrm{mol} / \mathrm{l}$ when water authority results were below $1.85 \mu \mathrm{mol} / \mathrm{l}$. There may, of course, have been a real change in water aluminium concentration in the interval between the two measurements. Both methods of analysis showed that very few of our patients were being supplied with untreated water containing between 1.0 and $1.85 \mu \mathrm{mol}$ aluminium per 1 , so that the highest concentration used without deionisation was in reality about $1.0 \mu \mathrm{mol} / 1$.

Figure 3 shows the concentrations of aluminium measured by electrothermal atomic absorption in paired samples of water before and after deionisation. When the untreated water contained more than $7.5 \mu \mathrm{mol} / 1(20.2 \mu \mathrm{g} / 100 \mathrm{ml})$ the concentration in the effluent from the deioniser was frequently above $1.0 \mu \mathrm{mol} / 1$, but when the concentration in untreated water was below $7.5 \mu \mathrm{mol} / 1$ the deioniser reduced the concentration to $1.0 \mu \mathrm{mol} / 1$ or less.

The plasma aluminium concentration was invariably less than $3.5 \mu \mathrm{mol} / 1(9.4 \mu \mathrm{g} / 100 \mathrm{ml})$ when the patient was using water which contained less than $1.0 \mu \mathrm{mol} / 1$ and not taking aluminium hydroxide. Plasma aluminium concentrations of $3.3 \mu \mathrm{mol} / 1(8.9 \mu \mathrm{g} / 100 \mathrm{ml})$ were 


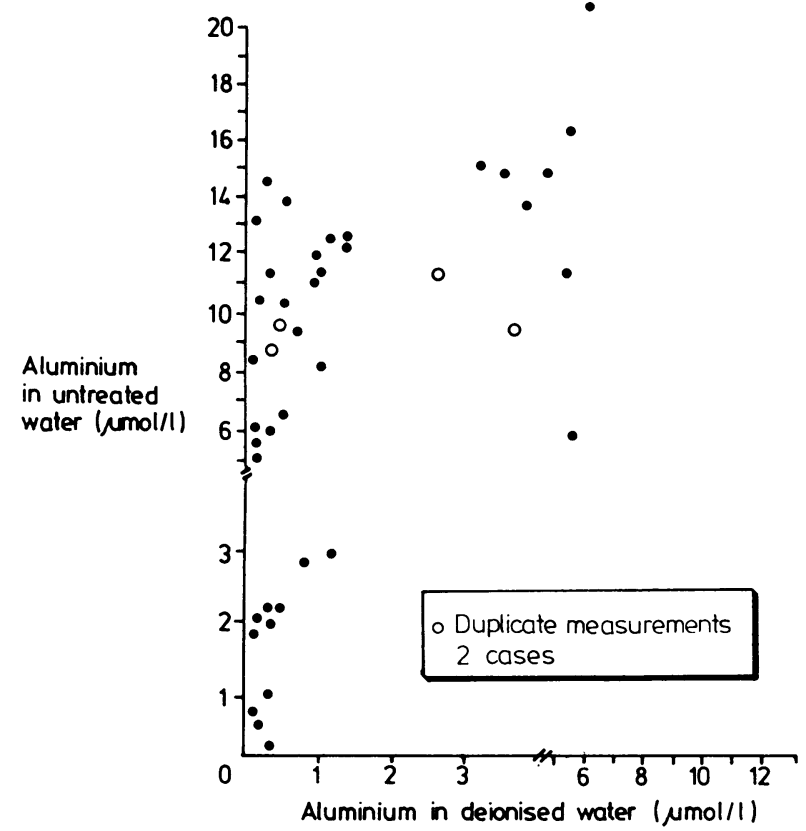

FIG 3-Aluminium concentrations in untreated and deionised specimens of water obtained simultaneously from patients' homes (measured by electrothermal atomic absorption).

Conversion: SI to traditional units-Aluminium: $1 \mu \mathrm{mol} / 1 \approx 2 \cdot 7 \mu \mathrm{g} /$ $100 \mathrm{ml}$.

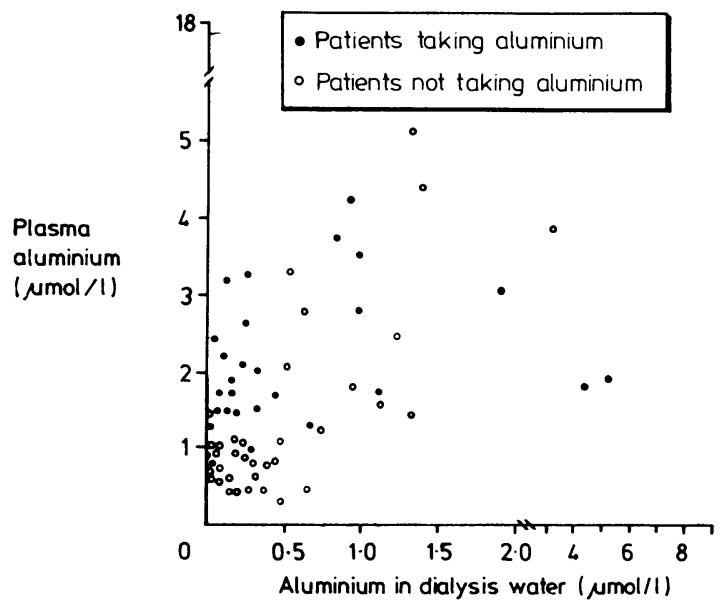

FIG 4-Correlation between plasma aluminium concentrations, concentrations of aluminium in water being used for haemodialysis, and ingestion of aluminium hydroxide. (Concentrations measured by electrothermal atomic absorption.)

Conversion: SI to traditional units-Aluminium: $1 \mu \mathrm{mol} / 1 \approx$ $2 \cdot 7 \mu \mathrm{g} / 100 \mathrm{ml}$.

observed when the water contained as little as $0.3 \mu \mathrm{mol} / 1(0.8 \mu \mathrm{g} /$ $100 \mathrm{ml}$ ) if aluminium hydroxide was being taken at the same time (fig 4).

\section{Discussion}

The incidence of fractures in patients receiving regular haemodialysis was four times higher in those using water with more than $1.0 \mu \mathrm{mol}$ aluminium per $1(2 \cdot 7 \mu \mathrm{g} / 100 \mathrm{ml})$ to prepare dialysate than in patients using water containing less aluminium. This occurred despite similar treatment with phosphate binders and vitamin $\mathrm{D}$ in all patients. It took about one year for the use of purified water to reduce the incidence of fractures. Thus the relatively high incidence of fractures among patients in group 1 up to 1975 was probably the result of their early dialysis in Lodge Moor using heavily contaminated water. Similarly, the effect of prior use of water containing aluminium was seen in the high incidence of fractures among patients in group 3 in 1978, which was the first year in which deionisers were used by patients at home.

There has recently been much discussion about the desirable concentration of aluminium in water used to prepare dialysate. A concentration of zero would be ideal, but water treatment and analysis become progressively more expensive as the target concentration diminishes. The maximum dialysate concentration at which aluminium is likely to be dialysed out of plasma is thought to be about $0.5 \mu \mathrm{mol} / 1(1.4 \mu \mathrm{g} / 100 \mathrm{ml}) .^{10}$ Approximately $0.3 \mu \mathrm{mol}$ aluminium per $1(0.8 \mu \mathrm{g} / 100 \mathrm{ml})$ is derived from dialysate concentrate; hence water aluminium must be reduced to less than $0.15 \mu \mathrm{mol} / 1(0.4 \mu \mathrm{g} / 100 \mathrm{ml})$ to achieve a dialysate aluminium concentration of less than $0.5 \mu \mathrm{mol} / 1(1.4 \mu \mathrm{g} / 100 \mathrm{ml})$.

Plasma aluminium concentration changes rapidly between dialyses and as a consequence of changes in the aluminium concentration of dialysate. ${ }^{11}$ The plasma value, therefore, does not accurately reflect total body aluminium stores, which cannot be measured clinically. Nevertheless, development of dialysis encephalopathy and fractures bears some relation to plasma aluminium concentration, and case reports suggest that patients are at risk when values exceed $7.5 \mu \mathrm{mol} / 1(20.2 \mu \mathrm{g} /$ $100 \mathrm{ml}) .^{12-14}$

We try to maintain the plasma aluminium concentration in our patients below $3.7 \mu \mathrm{mol} / 1(10.0 \mu \mathrm{g} / 100 \mathrm{ml})$. The concentration of aluminium in their dialysate, even when a deioniser is used, is often more than $0.5 \mu \mathrm{mol} / 1(1.4 \mu \mathrm{g} / 100 \mathrm{ml})$, yet no patient has developed dialysis encephalopathy, and the incidence of fractures has been reduced dramatically by the regimen described. This has occurred despite an increasing population of patients who have received dialysis for more than 10 years. Many patients who previously suffered frequent fractures have stopped doing so. Plasma aluminium concentrations were measured in 105 patients up to June 1982, and in only six did the value exceed $3.7 \mu \mathrm{mol} / \mathrm{l}(10.0 \mu \mathrm{g} / 100 \mathrm{ml})$ (fig 4) and only one had a concentration of over $7 \cdot 5 \mu \mathrm{mol} / 1(20 \cdot 2 \mu \mathrm{g} / 100 \mathrm{ml})$.

To obtain a water aluminium concentration of $0.15 \mu \mathrm{mol} / 1$ $(0.4 \mu \mathrm{g} / 100 \mathrm{ml})$ a very large proportion of our patients would require reverse osmosis apparatus in their homes, which would increase the cost of water purification considerably. The capital cost of a home reverse osmosis machine is currently $£ 2100$ and that of a deioniser $£ 700$. In our area heavily contaminated water may require a change of deioniser cartridge after every one to 15 dialyses (average about six) at a cost of $£ 20$ a time. A reverse osmosis machine used for equally contaminated water requires the prior use of a filter, which we find needs to be replaced for each dialysis at a cost of $£ 10$. The membranes of the reverse osmosis machines are robust and require infrequent replacement in the event of rupture at a cost of $£ 1000$.

Even reverse osmosis cannot be guaranteed to reduce the concentration of aluminium in water to less than $0.15 \mu \mathrm{mol} / \mathrm{l}$ $(0.4 \mu \mathrm{g} / 100 \mathrm{ml})$. Our suggestion that a concentration of $1.0 \mu \mathrm{mol} / \mathrm{l}$ $(2.7 \mu \mathrm{g} / 100 \mathrm{ml})$ or less is safe agrees with an epidemiological survey on the incidence of dialysis encephalopathy in the United Kingdom ${ }^{5}$ and the official recommendation of the Department of Health and Social Security. This concentration may be obtained from the routine water authority analyses, which are free of charge in Britain. If these results are regularly less than $1.0 \mu \mathrm{mol} / 1$ there is no need to monitor water regularly by electrothermal atomic absorption so long as the patient's serum aluminium concentration is measured regularly. Many water authorities, however, add aluminium hydroxide to water and deionisation or reverse osmosis is then required with monitoring of the aluminium concentration of the treated water. Deionisation is usually satisfactory when raw water contains less than $7.5 \mu \mathrm{mol}$ aluminium per $1(20.2 \mu \mathrm{g} / 100 \mathrm{ml})$, but when the water is more heavily contaminated reverse osmosis is likely to be required. It is probably more important to measure the concentration of aluminium regularly in the patient's serum than to test the water frequently. For safety 
plasma concentrations should be below $3.7 \mu \mathrm{mol} / 1(10.0 \mu \mathrm{g} /$ $100 \mathrm{ml}$ ); if this is exceeded the water should be rechecked.

We have confirmed the observation that ingestion of aluminium hydroxide contributes to raised plasma aluminium concentrations $^{1516}$ (fig 4). With adequate haemodialysis and administration of calcium carbonate many patients do not require aluminium hydroxide to control the plasma phosphate concentration. If aluminium hydroxide is needed then it must be taken with meals to keep the amount required to a minimum. Meticulous removal of the last trace of aluminium from dialysis water seems pointless when large amounts are being eaten.

We thank the Sheffield Area Kidney Association, the Chesterfield Kidney Patients' Association, and the Leverhulme Trust for financial help. We thank $\mathrm{Mr}$ Ron Cooper for the electrothermal atomic absorption analyses for aluminium. We also thank Professor $R M$ Loynes, of the department of probability and statistics, Sheffield University, who examined the data on the incidence of fractures. He found a significantly greater incidence of fractures in group 2 than in the other two groups but considered that the results were self evident and that the text would not be enhanced by detailed statistical analysis.

\section{References}

${ }^{1}$ Posen GA, Gray DG, Jaworski ZF, Couture R, Rashid A. Comparison of renal osteodystrophy in patients dialysed with deionised and nondeionised water. Trans Am Soc Artif Intern Organs 1972;18:405-9.

${ }^{2}$ Pierides AM. Dialysis dementia, osteomalacic fractures and myopathy: a syndrome due to chronic aluminium intoxication. Int $\mathcal{f}$ Artif Organs $1978 ; 1: 206-7$.

${ }^{3}$ Flendrig JA, Kruis H, Das HA. Aluminium intoxication: the cause of dialysis dementia. Proc Eur Dial Transplant Assoc 1976;13:355-63.
4 Platts MM, Goode GC, Hislop JS. Composition of the domestic water supply and the incidence of fractures and encephalopathy in patients on home dialysis. Br Med F 1977; ii :657-60.

s Parkinson IS, Ward MK, Feest TG, Fawcett RWP, Kerr DNS. Fracturing dialysis osteodystrophy and dialysis encephalopathy, an epidemiological survey. Lancet 1979; :406-9.

${ }^{6}$ Leather HM, Lewin IG, Calder E, Braybrooke J. Effect of water deionisers on "fracturing osteodystrophy" and dialysis encephalopathy in Plymouth. Nephron $1981 ; 29: 80-4$.

${ }^{7}$ Platts MM, Grech P, McManners T, Cochran M. Skeletal changes in patients treated by regular haemodialysis in the Sheffield area. $\mathrm{Br} \mathcal{f}$ Radiol 1973;46:585-93.

${ }^{8}$ Alfrey AC, LeGendre GR, Kaehny WD. The dialysis encephalopathy syndrome-possible aluminium intoxication. $N$ Engl $f$ Med 1976; 294:184-8.

${ }^{9}$ Dougan WK, Wilson AL. Absorptiometric determination of aluminium in water. A comparison of some chromogenic reagents and the development of an improved method. Analyst $1974 ; 99: 413-30$.

${ }^{10}$ Hodge KC, Day JP, O'Hara M, Ackrill P, Ralston AJ. Critical concentrations of aluminium in water used for dialysis. Lancet 1981 ;ii: 802-3.

"Kaehny WD, Alfrey AC, Holman RE, Shorr WJ. Aluminium transfer during haemodialysis. Kidney Int 1977;12:361-5.

12 Elliott HL, Macdougall AI. Aluminium studies in dialysis encephalopathy. Proc Eur Dial Transplant Assoc 1978;15:157-62.

${ }^{13}$ Buge A, Poisson M, Masson S, et al. Encephalopathie prolongeé et réversible chez un dialysé chronique. Responsabilité probable des sels d'aluminium. Nouv Presse Med 1978;7:2053-9.

${ }^{14}$ Ackrill P, Ralston AJ, Day JP, Hodge KC. Successful removal of aluminium from patient with dialysis encephalopathy. Lancet 1980;ii: 692-3.

${ }^{15}$ Boukari M, Rottembourg J, Jaudon MC, Clavel JP, Legrain M, Galli A. Influence de la prise prolongeé de gels d'alumine sur les taux seriques d'aluminium chez les patients atteints d'insuffisance rénale chronique. Nouve Presse Med 1978;7:85-8.

${ }^{16}$ Marsden SNE, Parkinson IS, Ward MK, Ellis HA, Kerr DNS. Evidence for aluminium accumulation in renal failure. Proc Eur Dial Transplant Assoc $1979 ; 16: 588-93$.

(Accepted 19 January 1984)

\section{SHORT REPORTS}

\section{Induction of hyperplasia and hypertrophy of pacinian corpuscles}

Pacinian corpuscles are subcutaneous tactile receptors that macroscopically look like fat globules. In man their dimensions are 1.5$3.0 \mathrm{~mm}$ by $0.75-1.5 \mathrm{~mm}$ and their density is $3-5 \mathrm{~cm}^{2}$. These measurements were obtained by examining subcutaneous tissues from the volar surfaces of the proximal phalanges of 11 fingers of two injured patients and five who had undergone Dupuytren fasciectomies. On cross section the corpuscle appears laminated and is often likened to an onion. This structure dampens ${ }^{1}$ and converts deforming forces into shortening or stretching of the central unmyelinated nerve fibre, which creates an action potential. ${ }^{2}$ Pacinian corpuscles are primarily concerned with fine touch and vibration, adapting to changes of pressure in a few milliseconds. ${ }^{1-4}$ They are normally found adjacent to a nerve or tendon and are easily identified.

The physiology of the pacinian corpuscle has been investigated extensively in animals but not in man.

\section{Case report}

A 60 year old man who had lost his eyesight at the age of 14 in an accident had spent his working life in light industry using power driven tools, including circular saws. He presented to the casualty department with horizontal volar laceration at the midshaft level of the proximal phalanges of his right ring and middle fingers. The wound had been caused by a newly acquired circular saw and had ragged edges. He had total anaesthesia beyond the laceration on his ring finger and on the ulnar side of his middle finger but no visible injury to tendons or blood vessels. This injury was potentially incapacitating as it was to his dominant hand, with which he had been able to read 80 pages of braille an hour, and he was an accomplished musician.

Under general anaesthesia, with a pneumatic tourniquet applied to the upper arm, both wounds were extended and explored and thorough wound toilet performed. It was immediately apparent that both fingers had a superabundance of large pacinian corpuscles: 11 were counted in $1 \mathrm{~cm}^{2}$, some being more than $4 \mathrm{~mm}$ long. Four were sent for histological examination, which confirmed their identity. Both digital nerves and one digital artery had been divided in the ring finger, and in the middle finger the ulnar digital nerve had been divided. The flexor tendons were intact. The digital nerves were mobilised to allow the substantial crushed areas to be cut back, the lesions were repaired, and the fingers immobilised.

After 12 weeks he could feel light touch and pin prick in his ring finger, although two point discrimination was less than in his uninjured hand. Recovery in his middle finger was only partial.

\section{Comment}

The necessity for blind people to have greater acuity of touch is easily understood. There have not been any reports, however, that the numbers and sizes of pacinian corpuscles can increase in response to increased demand for fine touch. Greater numbers give obvious sensory advantages, and larger size increases the corpuscle's ability to dampen coarser variations in pressure ${ }^{1}$ and so permits better appreciation of fine changes. Like the nervous system, they might be expected not to be able to replicate as they are the end organs of sensory nerves, but this is not supported by the observations in this case.

I conclude that pacinian corpuscles can undergo hyperplasia and hypertrophy in response to stimulus although the stimulus may have to be applied for many years.

I thank Mrs S E Allwood for typing this paper.

' Vander AJ, Sherman JH, Luciano DS. Human physiology: the mechanisms of body function. New York, London: McGraw-Hill, 1980.

2 Guyton AC. Textbook of medical physiology. Philadelphia, London: W B Saunders, 1981. 